\title{
MODEL BUDGET RUN DAN TUNAS INTEGRITAS DALAM PEMBELAJARAN EKONOMI SMA: EFEKTIVITAS DAN RESPONS PESERTA DIDIK
}

\author{
Ariyanti \\ Guru Ekonomi, SMA Negeri 1 Pasirian Kab. Lumajang \\ Email: ariyanti.smanpasirian@gmail.com
}

\begin{abstract}
Abstrak
Dalam pembelajaran ekonomi, peserta didikmengeluhkan banyaknya konsep, materi, hafalan, dan gambar kurva yang harus dipelajari. Pembelajaran ekonomi juga dianggap terlalu membosankan dengan pembelajaran monoton yang berpusat pada guru. Untuk mengatasi permasalahan tersebut, tulisan ini menawarkan model pembelajaran yang dapat diterapkan dan menyenangkan berbasis cooperative learning dan kelompok, dikemas dalam suasana games, mewadahi tipe belajar peserta didik yang beragam dan penuh dengan pendidikan karakter yang dinamakan model Budget Run dan Tunas Integritas. Penelitian ini bertujuan untuk mengembangkan dan menguji efektivitas di kelas XI IPS 1. Metode penelitian yang digunakan adalah model riset dan pengembangan $(R \& D)$ Plomp yang dikombinasikan dengan Penelitian Tindakan Kelas (PTK). Tahapan dalam penelitian pengembangan ini meliputi Preliminary Investigation, Design and Develop, Realization, Test Evaluation and Revision, dan Implementation. Hasil penelitian menunjukkan bahwa penerapan Budget Run dan Tunas Integritas (TI) dapat meningkatkan hasil belajar, serta respons dan minat peserta didik.
\end{abstract}

Kata kunci: pembelajaran ekonomi, budget run, cooperative learning, tunas integritas

\section{Pendahuluan}

Ada beberapa permasalahan utama dalam pembelajaran ekonomi di tingkat SMA. Pertama, banyaknya konsep, materi, hafalan, dan gambar kurva yang harus dipelajari oleh peserta didik (Ariyanti, 2016; Putri, 2014). Permasalahan kedua adalah bahwa pembelajaran ekonomi terlalu membosankan dan tinggi penekanan pada hafalan (Noland \& Kelly, Worthingtin \& Higgs, Jackling \& Calero, Hutching \& Brown, dan Rond \& Shanahan dalam Ellis, Sundmacher \& Varua, 2011). Kondisi pembelajaran yang cenderung monoton dan teacher centered semakin memperparah suasana pembelajaran. Hal senada juga terjadi baik di dalam dan di luar negeri. Penelitian Nuraini (2014) menyatakan peserta didik tidak menyukai metode yang digunakan oleh guru.

Permasalahan ketiga yaitu pembelajaran ekonomi jauh dari realitas ekonomi konkret yang terjadi di masyarakat. Peserta didik mengeluhkan penggunaan rumus matematis, perhitungan dan model dalam ekonomi sepertinya tidak berguna. Peserta didik menganggap tidak ada relevansi ekonomi yang diajarkan dengan dunia nyata. Beberapa penelitian mengungkap permasalahan yang sama seperti (Becker, 2004; Lim, 2016; Yeunglamko, 2011). Penurunan jumlah mahasiswa jurusan ekonomi di Australia dibanding dengan jurusan bisnis diindikasikan karena ekonomi terlalu membosankan dan jauh dari realitas nyata (Stokes \& Wright, 2012)

Ketiga permasalahan di atas dapat diatasi dengan mengembangkan sebuah pembelajaran yang tidak membosankan, menyenangkan, berorientasi pada kondisi nyata di masyarakat dan mewadahi tipe belajar peserta didik yang beragam. Untuk itulah Model Budget Run dan Tunas Integritas dikembangkan. Budget Run yang dikombinasikan dengan Tunas Integritas (TI) adalah sebuah model pembelajaran yang dirancang berdasarkan kebutuhan peserta didik pada materi APBN di kelas XI. Budget Run dalam penerapannya akan dipadukan dengan games (permainan) 
agar pembelajaran menjadi menyenangkan dan memecah kebosanan (Sato de Haan, 2016), membangun suasana kompetitif, mengajarkan ketrampilan memecahkan masalah, (Rodkroh, Suwannatthachote, \& Kaemkate, 2013) dan mampu meningkatkan minat dan keaktifan peserta didik (Nancy A. Neef et al., 2011).

Budget Run secara harfiah bahasa berarti "anggaran berlari", istilah ini dibuat karena peserta didik memang dituntut berlari cepat menemukan kelompok induk anggaran dalam APBN sesuai dengan undian kasus nyata yang ia dapatkan dan dibatasi durasi tertentu. Sedangkan Tunas Integritas adalah sebuah bentuk tugas akhir yang dikerjakan peserta didik melalui media sosial seperti Facebook dan Instagram. Peserta didik diminta mengunggah foto atau video dengan tema seputar pendapatan dan untuk apa uang negara dibelanjakan pada media sosial masing-masing, dengan menggunakan ajakan positif untuk ikut serta menghemat, dan memanfaatkan belanja APBN dan APBD sebaik mungkin. Boleh dibilang, Tunas Integritas pada pembelajaran ekonomi ini adalah sebuah langkah kecil dalam upaya penanaman pendidikan anti korupsi kepada peserta didik melalui pembelajaran dan media sosial.

Penelitian Mardiana (2016) menyatakan bahwa ada kesempatan besar menggunakan media sosial dalam pendidikan. Beberapa penelitian menunjukkan bahwa media sosial menyediakan lingkungan yang baik untuk menunjang kegiatan pendidikan dengan memberikan kemudahan, interaksi, kolaborasi, partisipasi, berbagi informasi dan sumber daya serta pemikiran kritis (Bosch, 2009; Mali \& Hassan, 2013). Meski tidak dipungkiri, media sosial juga memiliki efek negatif.

Penelitian dilaksanakan di SMA Negeri 1 Pasirian, karena beberapa permasalahan yang didentifikasi di awal penelitian ditemukan di sekolah ini. Penerapan model Budget Run dan Tunas Integritas (TI) diharapkan dapat mengatasi permasalahan yang terjadi dalam pembelajaran ekonomi.

Berdasarkan alasan tersebut penelitian ini bertujuan mengembangkan Model Pembelajaran Ekonomi Budget Run yang dikombinasikan dengan TI, mengukur efektivitas, serta mengetahui respons dan minat peserta didik terhadap penerapan model Budget Run dan Tunas Integritas (TI). Hasil penelitian ini diharapkan dapat bermanfaat bagi peserta didik untuk dapat meningkatkan respons dan minat belajar peserta didik, mendorong munculnya daya pikir kritis, logis dan sistematis. Serta, membantu peserta didik untuk memperoleh keterampilan pembuatan keputusan, berkomunikasi, serta menumbuhkembangkan sikap peduli dan perilaku anti korupsi. Sedangkan bagi guru dan sekolah, penelitian ini bisa dijadikan bahan masukan dalam menghadirkan proses belajar mengajar yang berkualitas dan berkarakter. Serta dapat menginspirasi mata pelajaran lain dalam rangka mengembangkan model, strategi dan metode pembelajaran sehingga diperoleh perbaikan output melalui inovasi pembelajaran di sekolah.

\section{BELAJAR DAN PEMBELAJARAN KONTEKSTUAL}

\section{Belajar}

Naluri manusia untuk mengetahui berbagai macam perkembangan ilmu menuntut dirinya untuk belajar. Dari kata belajar inilah kemudian lahir kata pembelajaran. Setelah belajar orang memiliki keterampilan, pengetahuan, sikap dan nilai. Timbulnya kemampuan tersebut berasal dari (1) stimulus yang berasal dari lingkungan dan (2) proses kognitif yang dilakukan pebelajar. Sehingga, belajar adalah seperangkat proses kognitif yang mengubah sifat stimulasi lingkungan, melewati pemrosesan informasi menjadi kemampuan baru.

Belajar dan pembelajaran memiliki perbedaan makna. Belajar berfokus pada proses yang terjadi pada diri dan seluruh proses mental ketiga ranah yakni pengetahuan (kognitif), sikap (afektif) dan praktek (psikomotor). Sedangkan pembelajaran menunjuk pada kegiatan untuk menciptakan lingkungan yang mampu mendorong dan mendukung terjadinya interaksi antara guru dan 
peserta didik. Salah satu cara agar peserta didik terlibat secara aktif dan tercipta lingkungan yang menumbuhkan minat belajar peserta didik, yaitu dengan memilih dan menentukan strategi pembelajaran yang tepat.

Model Budget Run yang dikombinasikan dengan Tunas Integritas memiliki kelebihan dalam perbandingan fakta di lapangan yang akan memperkuat konsep, serta prosedur dan prinsip yang digunakan demi tercapainya tujuan pembelajaran. Dengan proses ini, Budget Run dan TI diharapkan dapat membuat pembelajaran semakin bermakna bagi peserta didik. Terdapat berbagai macam pendekatan yang bisa digunakan dalam proses belajar mengajar. Salah satu yang bisa digunakan adalah pendekatan kontekstual yang sampai saat ini masih terus digunakan dan dikembangkan.

\section{Pendekatan Konteksual}

Nurhadi (2002) menyatakan, pembelajaran kontekstual (Contextual Teaching and Learning) adalah sebuah konsep belajar yang mengaitkan antara materi yang diajarkan dengan situasi dunia nyata peserta didik. Diharapkan, dengan konsep seperti ini, hasil pembelajaran akan menjadi lebih bermakna bagi peserta didik. Dasar dari pembelajaran kontekstual adalah konstruktivisme yang menekankan proses pembelajaran agar peserta didik mengkonstruk pengetahuan mereka sendiri. Dalam pembelajaran, pengalaman dan potensi yang sudah terbentuk di dalam diri peserta didik diberdayakan oleh guru secara maksimal. Sehingga, kreatifitas dan keaktifan peserta didik menjadi hal utama bagi peserta didik untuk mendapatkan dan menguasai pengetahuan.

Beberapa perbedaan penting antara pendekatan kontekstual berorientasi konstruktivism dengan pendekatan konvensional berorientasi behaviorism, dapat dilihat pada tabel 1 berikut:

Tabel 1 : Perbandingan Pendekatan Pembelajaran Kontekstual Dengan Pendekatan Pembelajaran Konvensional

\begin{tabular}{lll}
\hline No & \multicolumn{1}{c}{ Pendekatan CTL } & \multicolumn{1}{c}{ Pendekatan Konvensional } \\
\hline 1 & $\begin{array}{l}\text { Dalam proses pembelajaran, peserta didik } \\
\text { terlibat secara aktif, berpikir kritis, dan ikut } \\
\text { ambil bagian pada proses pembelajaran } \\
\text { yang efektif. }\end{array}$ & $\begin{array}{l}\text { Peserta didik sebagai penerima informasi } \\
\text { secara pasif tanpa ikut ambil bagian pada } \\
\text { proses pembelajaran yang efektif }\end{array}$ \\
\hline 2 & Student centered & Teacher centered \\
\hline 3 & $\begin{array}{l}\text { Peserta didik belajar dari komunitas } \\
\text { pembelajar seperti teman melalui kerja } \\
\text { kelompok,sharing ide, koreksi }\end{array}$ & Peserta didik belajar secara individu \\
\hline 4 & $\begin{array}{l}\text { Pembelajaran dikaitkan dengan kehidupan } \\
\text { nyata dan atau yang disimulasikan }\end{array}$ & $\begin{array}{l}\text { Pembelajaran jauh dari kenyataan yang } \\
\text { ada dan sangat teoritis }\end{array}$ \\
\hline 5 & $\begin{array}{l}\text { Perilaku dibangun atas dasar kesadaran } \\
\text { diri, kebermanfaatan dan pemahaman }\end{array}$ & $\begin{array}{l}\text { Perilaku dibangun atas dasar kebiasaan } \\
\text { seperti reward \& punishment (hadiah \& } \\
\text { hukuman) }\end{array}$ \\
\hline 6 & $\begin{array}{l}\text { Tingginya penghargaan terhadap } \\
\text { pengalaman peserta didik }\end{array}$ & $\begin{array}{l}\text { Kurangnya perhatian terhadap pengalaman } \\
\text { peserta didik }\end{array}$ \\
\hline 7 & $\begin{array}{l}\text { Alat ukur hasil belajar sangat beragam } \\
\text { seperti proses, bekerja, produk, } \\
\text { penyajian, tes, dan lain-lain }\end{array}$ & $\begin{array}{l}\text { Satu-satunya alat ukur hasil belajar adalah } \\
\text { tes }\end{array}$ \\
\hline
\end{tabular}

Sumber : Hasnawati (2006 : 59) 


\section{MODEL BUDGET RUN DAN TUNAS INTEGRITAS DALAM PEMBELAJARAN EKONOMI SMA}

Istilah Budget Run dalam bahasa Inggris bermakna anggaran berlari karena peserta didik memang dituntut berlari cepat menemukan kelompok induk anggaran dalam APBN sesuai dengan undian kasus nyata yang ia dapatkan dan dibatasi durasi tertentu. Budget Run dimainkan 4-5 orang pemegang induk anggaran yang disebut kepala (Chief), dengan jumlah anggota yang tidak ditentukan. Chief berhak menolak atau mengajak seseorang masuk ke dalam kelompoknya. Meski pertimbangan dari anggota lain tidak bisa diremehkan. Artinya benar atau tidaknya jawaban analisis kasus menjadi tanggung jawab bersama. Pemenang ditentukan berdasar jumlah skor tertinggi bagi kelompok yang memilki kesalahan jawaban paling sedikit dalam menganalisis kasus.

Budget Run merupakan model pembelajaran berbasis pembelajaran kerja kelompok, pembelajaran kooperatif dan adaptasi dari make a match. Model ini menekankan proses dan kegiatan belajar pada interaksi antar peserta didik. Pembelajaran kerja kelompok dan pembelajaran kooperatif terdiri dari beberapa peserta didik yang bekerjasama dalam kelompok kecil (biasanya dua sampai lima peserta didik) dalam struktur tugas yang jelas (Slavin dalam Eggen \& Kauchak, 2012). Keberhasilan dan kegagalan tim secara keseluruhan ditentukan oleh kontribusi individu-individu dan sejauh mana peran mereka dalam membantu kelompok (Cruischank, Jenkins, \& Metcalf, 2014).

Pembelajaran kooperatif mendorong peserta didik bekerjasama, baik untuk kepentingan individu maupun kelompok. Saat bekerjasama peserta didik mendapatkan pengalaman yang dapat mendorong sejumlah ketrampilan sosial seperti : menyimak dengan penuh perhatian, negosiasi dan menyelesaikan ketidaksepakatan, serta kemampuan menerima satu sama lain (Eggen \& Kauchak, 2012). ada karakteristik utama yang perlu menjadi perhatian saat menerapkan pembelajaran kerja kelompok dan pembelajaran kooperatif :

1. Cara kelompok atau tim dibentuk, keragaman (heterogenitas) anggota kelompok mutlak diperlukan. Heterogenitas ini sendiri akan menguntungkan peserta didik dengan kemampuan rendah karena dapat meningkatkan prestasinya dalam kelompok yang beragam daripada kelompok yang homogen (Slavin dalam Cruischank, Jenkins, \& Metcalf, 2014)

2. Persiapan bahan, materi dan tugas yang akan diberikan kepada kelompok, penugasan yang diberikan dalam kelompok adalah hal yang sangat penting, karena jika dibiarkan bekerja tanpa tugas yang jelas, peserta didik cenderung membahas masalah sosial dan pribadi meningkat tajam. (Cruischank, Jenkins, \& Metcalf, 2014; Eggen \& Kauchak, 2012)

3. Peraturan kelompok, karakteristik utama dari pembelajaran kooperatif dan kerja kelompok adalah peraturan yang dituntut dari tim. Selain itu guru perlu menerapkan aturan lain seperti: kelompok harus menghasilkan sesuatu, dan menentukan durasi waktu penyelesaian tugas, termasuk memonitor kelompok saat bekerja (Cruischank, Jenkins, \& Metcalf, 2014; Eggen \& Kauchak, 2012)

4. Sistem penghargaan yang unik, daripada nilai yang didasarkan pada usaha pribadi, pembelajaran kooperatif dan kerja kelompok menerima nilai individu berdasarkan kinerja tim. (Cruischank \& Jenkins \& Metcalf, 2014)

Budget Run memiliki empat tahapan yang disebut A-A-B-C (Amati-Analisis-Berlari-Ceritakan). Berikut ini adalah penjelasan dari tiap tahapan tersebut:

1. Amati, tahapan awal Budget Run dimulai dengan pengamatan peserta didik pada tabel dan gambar tentang APBN dan realisasi.

2. Analisis, setiap individu berpasangan dalam kelompok (4-5 anggota) melakukan analisis agar penguasaan terhadap materi semakin meningkat. Analisis awal dilakukan dengan tipe jawaban seragam, agar peserta didik menguasai materi. Analisis lanjutan berupa pertanyaan 
dengan jawaban beragam tergantung pada hasil diskusi kelompok. Hal ini akan mendorong diskusi, review dan tanya jawab dapat dilakukan.

3. Berlari, feedback pada kedua tahapan sebelumnya (amati-analisis) dilakukan pada tahapan ini. Individu peserta didik diminta mengambil undian kasus nyata yang harus dianalisis secara individu. Ada 4-5 orang kepala (Chief) anggaran yang telah dipilih guru untuk memegang bendera bertuliskan induk anggaran APBN/APBD. Chief berhak menolak atau mengajak seseorang masuk ke dalam kelompoknya dengan durasi waktu terbatas.

4. Ceritakan, Tahap akhir dalam Budget Run yakni menceritakan (mengkomunikasikan) alasan setiap individu dalam memilih induk anggaran. Tahapan ini memungkinkan terjadinya diskusi seru dan atmosfir kompetitif antar kelompok. Proses ini mutlak dilakukan karena pada tahap inilah peserta didik menyimpulkan pandangan-pandangan, menghubungkan undian kasus nyata yang mereka dapat dengan materi, serta menggali pemahaman peserta didik akan hikmah yang bisa diambil.

Keseluruhan tahapan di atas dirancang untuk mewadahi tipe belajar peserta didik, para peserta didik dengan tipe belajar visual misalnya, akan sangat menyukai mengamati gambar dan tabel APBN yang harus dianalisis. Para peserta didik dengan tipe kinesthetik, akan berlari dengan cepat karena tipe belajar ini mudah bosan jika tidak melakukan aktivitas (Stokes \& Wright, 2012). Budget Run juga mengimplementasikan kecakapan abad 21 seperti berpikir kritis dan pemecahan masalah (critical thinking and problem solving skill) saat mencari dan memilih induk anggaran. Berkolaborasi (collaboration) dengan kelompok, serta kecakapan komunikasi (communication skill) saat menceritakan hasil analisis kolaborasi dengan kelompok.

Sedangkan Tunas Integritas terinspirasi dari sebuah program anti korupsi yang disebut "Tunas Integritas" dari Komisi Pemberantasan Korupsi (KPK) pada Deputi Pencegahan. Pendidikan antikorupsi diyakini mampu mencegah korupsi lebih efektif. Karena, prinsip pendidikan adalah penanaman nilai-nilai dan budaya yang akan lebih membekas dan akan menggerakkan kita berperilaku lebih baik. Ini pula yang diyakini Komisi Pemberantasan Korupsi (KPK) dalam program Tunas Integritas. Program ini diimplementasikan kepada semua elemen masyarakat, tanpa terkecuali (www.kpk.go.id).

Tunas Integritas dalam penelitian ini adalah sebuah bentuk tugas akhir pembelajaran materi APBN dan APBD yang dikerjakan peserta didik melalui media sosial seperti Facebook dan Instagram. Konsep Tunas Integritas (TI) ini muncul sebagai respons atas beberapa pertanyaan peserta didik yang menggelitik tentang begitu banyaknya kasus korupsi di negeri ini. Sehingga pada akhirnya konsep TI ini mulai dikombinasikan dengan Budget Run pada materi APBN. Harapan dari pengembangan Budget Run dan Tunas Integritas ini adalah peserta didik tidak hanya mampu menganalisis APBN, tetapi juga mulai peduli, mensosialisasikan dan mengajak orang lain agar APBN dan APBD dimanfaatkan sebaik mungkin, karena APBN dan APBD adalah uang kita bersama (kemenkeu.go.id).

\section{METODE PENELITIAN}

Penelitian ini menggunakan model riset dan pengembangan (R \& D) yang dikombinasikan dengan penelitian tindakan kelas (PTK) untuk mengukur keefektifan model Budget Run dan Tunas Integritas. Model pengembangan mengacu pada desain pembelajaran model Plomp. Alasan pemilihan model ini dikarenakan model Plomp lebih fleksibel dan luwes. Menurut Plomp (2013) tahapan dalam penelitian pengembangan meliputi 5 (lima) fase mulai dari (1) Preliminary Investigation (2) Design and Develop (3) Realization (4) Test, Evaluation and Revision dan (5) Implementation.

Penelitian diujicobakan di kelas XI IPS 1 di SMAN 1 Pasirian, pada kompetensi dasar (KD) 3.6 Menganalisis APBN dan APBD dalam pembangunan ekonomi serta 4.6 Menyajikan hasil 
analisis fungsi dan peran APBN dan APBD dalam pembangunan ekonomi. Pengukuran efektivitas dilakukan menggunakan tiga kriteria Van den Akker (1999): kevalidan (validity), kepraktisan (practically), dan keefektifan (effectivity). Untuk uji kevalidan dan kepraktisan akan dilakukan melalui uji ahli yakni praktisi pengguna/guru. Sedangkan untuk kriteria keefektifan dilaksanakan melalui Penelitian Tindakan Kelas (PTK) pada kelas XI IPS 1.

\section{HASIL PENELITIAN DAN PEMBAHASAN}

Ide pengembangan model Budget Run dan Tunas Integritas (TI) didorong banyaknya keluhan peserta didik tentang menahan kantuk dan betapa membosankannya pelajaran di jam-jam terakhir. Keluhan ini berujung pada keinginan untuk menciptakan kelas pembelajaran ekonomi yang menyenangkan, tidak membosankan, sekaligus membantu peserta didik memahami materi APBN-APBD dengan lebih mudah.

Pengembangan produk diawali dengan fase investigasi awal (Preliminary Investigation) yang dimulai dengan melakukan identifikasi permasalahan di lapangan meliputi analisis kebutuhan serta studi literatur dan kajian pustaka. Analisis kebutuhan dilakukan agar permasalahan-permasalahan yang ada di lapangan dapat diidentifikasi, temuan permasalahan diperoleh berdasarkan hasil wawancara dan observasi. Sehingga pada studi literatur dan kajian pustaka dirujuk beberapa teori, dan penelitian yang relevan untuk mengatasi permasalahan dan mengoptimalkan potensi yang ada. Langkah selanjutnya yakni fase desain dan pengembangan (Desain and Develop), pada tahap ini dilakukan perencanaan, pengembangan, dan persiapan macam-macam kebutuhan penelitian. Produk yang direncanakan berupa (1) Model Budget Run dan TI dalam bentuk buku panduan dan perlengkapannya, (2) Perangkat Pembelajaran berupa silabus, RPP, penilaian serta (3) Lembar Kerja Peserta Didik (LKPD). Rencana tersebut mulai dibuat atau diwujudkan pada fase realisasi (realization). Di akhir, produk pengembangan melalui fase Tes, Evaluasi, dan Revisi (Test, Evaluation, and Revision) dilakukan uji kevalidan, kepraktisan, dan keefektifan (Van de Akker, 1999). Hasil uji kevalidan dan kepraktisan melalui uji ahli dari praktisi pengguna/guru sebagai berikut :

Tabel 2. Hasil Validasi Ahli terhadap Model Budget Run dan TI

\begin{tabular}{lllll}
\hline \multirow{2}{*}{ No } & \multicolumn{1}{c}{ Aspek Penilaian } & \multicolumn{3}{c}{ Penilaian } \\
\cline { 3 - 5 } & & Ahli 1 & \multicolumn{1}{c}{ Ahli 2 } & Ahli 3 \\
\hline A & $\begin{array}{l}\text { Kaitan Model dan Masalah } \\
\text { Pembelajaran }\end{array}$ & Baik & Sangat Baik & Sangat Baik \\
\hline B & Landasan Teori & Sangat Baik & Sangat Baik & Sangat Baik \\
\hline C & Prosedur/Sintaks Pembelajaran & Sangat Baik & Baik & Sangat Baik \\
\hline D & Karakter Peserta Didik & Sangat Baik & Baik & Sangat Baik \\
\hline E & Peningkatan Proses Pembelajaran & Sangat Baik & Sangat Baik & Baik \\
\hline F & Pengaruh terhadap Hasil Belajar & Sangat Baik & Sangat Baik & Sangat Baik \\
\hline G & $\begin{array}{l}\text { Penilaian Umum terhadap Model } \\
\text { Budget Run dan TI }\end{array}$ & Sangat Baik & Baik & Sangat Baik \\
\hline
\end{tabular}

Sumber : diolah berdasarkan uji validasi ahli 
Tabel 3. Hasil Validasi Ahli terhadap Perangkat Pembelajaran dan LKPD

\begin{tabular}{|c|c|c|c|c|c|}
\hline \multirow{2}{*}{ No } & \multirow{2}{*}{$\begin{array}{c}\text { Aspek } \\
\text { Penilaian }\end{array}$} & \multicolumn{3}{|c|}{ Penilaian } & \multirow{2}{*}{ Penilaian Umum } \\
\hline & & Ahli 1 & Ahli 2 & Ahli 3 & \\
\hline 1 & $\begin{array}{l}\text { Perangkat } \\
\text { Pembelajaran }\end{array}$ & Sangat Baik & Baik & Sangat Baik & $\begin{array}{l}\text { Dapat digunakan } \\
\text { dengan sedikit Revisi }\end{array}$ \\
\hline 2 & LKPD & Baik & Baik & Sangat Baik & $\begin{array}{l}\text { Dapat digunakan } \\
\text { dengan Sedikit Revisi }\end{array}$ \\
\hline
\end{tabular}

Sumber : diolah berdasarkan uji validasi ahli

Jika diamati berdasarkan validasi ahli terhadap Model Budget Run dan TI, Perangkat Pembelajaran dan LKPD, secara umum mendapatkan penilaian sangat baik dan dapat digunakan dengan sedikit revisi. Sedangkan untuk uji kepraktisan (Practically), Tim Ahli yang terdiri dari praktisi serta guru pengguna berdasarkan lembar validasi butir C (dapat dilihat pada tabel 2) terhadap model Budget Run dan TI, menyatakan bahwa model Budget Run dan TI memuat tahapan yang jelas dan dapat diterapkan di kelas.

Meski secara umum dinilai baik, namun ada beberapa revisi berdasarkan saran dari tim ahli yakni : refleksi di akhir pembelajaran harus dimaksimalkan, karena menjadi kekuatan bagi guru untuk menanamkan karakter peduli, kegiatan membaca sumber belajar diganti menjadi menyaksikan video dan tayangan berita untuk memaksimalkan proses berpikir dan ketertarikan peserta didik, serta pengembangan kasus dan papan induk anggaran dalam lingkup yang lebih luas.

Sedangkan uji keefektifan dilakukan untuk mengetahui efektivitas penggunaan model pembelajaran yang dikembangkan. Dilakukan pada satu rombongan belajar yakni kelas XI IPS 1, di SMA Negeri 1 Pasirian Kabupaten Lumajang. Uji efektivitas dilakukan melalui penelitian tindakan kelas (PTK). Pelaksanaan pembelajaran pada hari Senin dan Selasa. Secara berturutturut dilaksanakan pada tanggal 7, 13, 14, 20, dan 21 Agustus 2018 dengan langkah sebagai berikut:

(a) Pelaksanaan Tindakan. Pada pelaksanaan tindakan, peneliti sekaligus berperan sebagai guru model di kelas. Sedangkan Observer adalah guru mata pelajaran ekonomi di kelas XI yang lain. Berdasarkan lembar observasi pelaksanaan model Budget Run dan TI pada materi APBN-APBD, pengamat memberikan penilaian positif dikarenakan terlaksananya seluruh aspek. Penerapan model Budget Run dan TI terbagi menjadi empat tahapan yakni Amati-Analisis-Berlari-Ceritakan. Karena terbatasnya durasi jam pelajaran, maka keempat tahap tersebut tidak dilakukan secara bersama, pertemuan pertama tahap amati dan analisis, sedangkan tahap berlari dan ceritakan dilaksanakan pada pertemuan berikutnya. Fokus pertemuan pertama dan kedua pada APBN, sedangkan pada pertemuan ketiga dan keempat menitikberatkan pada konsep APBD.

(b) Hasil Pengamatan. Beberapa temuan penting di lapangan yang tidak terekam dalam lembar observasi merupakan hasil pengamatan, yakni : pada pengerjaan LKPD, beberapa peserta didik masih melihat jawaban kelompok lain, sehingga ada aturan pengurangan skor bagi yang melanggar. Minimnya kerjasama antar anggota, sehingga pengerjaan analisis kelompok menghabiskan waktu lebih lama dari yang ditetapkan, Saat undian kasus dilakukan, peserta didik menukar undian kasus yang mereka peroleh. Hal ini diatasi dengan memasukkan undian kasus ke dalam sedotan berwarna gelap pada pertemuan berikutnya.

(c) Refleksi. Refleksi diharapkan menjadi dasar untuk perlu atau tidak tindakan lanjutan dilakukan Berdasarkan pengamatan, paparan data ketuntasan belajar peserta didik, serta respons peserta didik selama tindakan dilakukan, maka tidak diperlukan tindakan lanjutan karena ketuntasan belajar peserta didik, respons dan minat peserta didik dalam pembelajaran sudah baik 
Efektivitas Model Budget Run yang dikombinasikan dengan Tunas Integritas (TI) diketahui berdasarkan nilai yang diperoleh peserta didik dalam mengerjakan soal tes evaluasi sebelum (pretest) dan sesudah (posttest) menggunakan model yang dikembangkan. Perbandingan hasil belajar peserta didik kelas XI IPS 1 dengan menerapkan model Budget Run dan TI dapat dilihat pada Tabel 4 berikut ini :

Tabel 4. Perbandingan Hasil Belajar Kelas XI IPS 1

\begin{tabular}{rlcc}
\hline No & \multicolumn{1}{c}{ Keterangan } & Sebelum Tindakan & $\begin{array}{c}\text { Sesudah } \\
\text { Tindakan }\end{array}$ \\
\hline 1 & Jumlah Peserta Test $(\mathrm{N})$ & 33 & 33 \\
\hline 2 & Skor Terkecil & 21 & 61 \\
\hline 3 & Skor Tertinggi & 79 & 94 \\
\hline 4 & Jumlah Tuntas Belajar & $7(21 \%)$ & $27(79 \%)$ \\
\hline 5 & Jumlah Tidak Tuntas Belajar & $26(78 \%)$ & $6(22 \%)$ \\
\hline
\end{tabular}

Berdasarkan data pada tabel 4 tentang perbandingan hasil belajar kelas XI IPS 1, diketahui bahwa sebanyak 27 Peserta Didik telah tuntas belajar, sedangkan 6 lainnya belum tuntas jika dibandingkan dengan KKM (Kriteria Ketuntasan Minimal) yang ditetapkan yakni 75. Penetapan nilai KKM ini berdasarkan dokumen Buku 1 KTSP SMAN 1 Pasirian.

Jumlah 27 peserta didik ini lebih banyak dibandingkan hasil sebelum tindakan dilakukan, dimana hanya ada 7 peserta didik yang tuntas belajar. Dengan demikian dapat disimpulkan bahwa penerapan Model Budget Run yang dikombinasikan dengan Tunas Integritas (TI) dapat meningkatkan hasil belajar.

Sedangkan hasil analisis berdasarkan angket respons dan minat peserta didik menggunakan model Budget Run dan TI dijelaskan pada tabel 5 tentang respons dan minat peserta didik terhadap Model Budget Run dan TI.

Tabel 5. Respons dan Minat Peserta Didik terhadap Model Budget Run dan Tunas Integritas (TI)

\begin{tabular}{lc}
\hline \multicolumn{1}{c}{ Sub Indikator } & Penilaian (\%) \\
\hline Tanggapan terhadap model Budget Run dan Tunas Integritas & $91 \%$ \\
\hline $\begin{array}{l}\text { Kemudahan memahami instruksi guru dalam pembelajaran dengan model } \\
\text { Budget Run dan TI }\end{array}$ & $91 \%$ \\
\hline $\begin{array}{l}\text { Model Budget Run dan TI dapat meningkatkan keaktifan dan motivasi } \\
\text { belajar }\end{array}$ & $81 \%$ \\
\hline $\begin{array}{l}\text { Model Budget Run dan TI memudahkan pemahaman terhadap jenis } \\
\text { pendapatan dan belanja negara }\end{array}$ & $85 \%$ \\
\hline $\begin{array}{l}\text { Model Budget Run dan TI mengajarkan peserta didik bekerjasama, membuat } \\
\text { keputusan, mengemukakan alasan, menyimpulkan dan menyampaikan } \\
\text { pendapat }\end{array}$ & $85 \%$ \\
\hline $\begin{array}{l}\text { Model Budget Run dan TI mengajarkan bagaimana sikap peduli terhadap } \\
\text { terhadap APBN }\end{array}$ & $97 \%$ \\
\hline $\begin{array}{l}\text { Model Budget Run dan TI mengajarkan bahwa kepedulian terhadap APBN } \\
\text { adalah tanggung jawab kita bersama }\end{array}$ & $98 \%$ \\
\hline
\end{tabular}

Berdasarkan data diatas, diketahui bahwa respons peserta didik positif terhadap model Budget Run dan TI. Peserta didik menyatakan senang belajar dengan model Budget Run dan TI karena menghilangkan kebosanan saat proses belajar mengajar. Peserta didik setuju model ini memudahkan peserta didik dalam memahami jenis-jenis pendapatan dan belanja negara-daerah, bekerjasama dan mengungkapkan pendapat. Hal ini sesuai dengan kelebihan pembelajaran kelompok dan kooperatif, dimana saat bekerjasama peserta didik mendapatkan pengalaman yang dapat mendorong sejumlah ketrampilan sosial seperti : menyimak dengan penuh perhatian, 
negosiasi dan menyelesaikan ketidaksepakatan, serta kemampuan menerima satu sama lain (Eggen \& Kauchak, 2012) Peserta didik juga sepakat bahwa Budget Run dan TI mengajarkan kepedulian bahwa APBN dan APBD adalah tanggung jawab bersama, karena APBN adalah uang kita.

Tahapan penyempurnaan produk, evaluasi, dan uji validitas, kepraktisan, efektifitas telah dilaksanakan sejalan dengan tiga kriteria Van den Akker (1999) dan mendapatkan hasil baik, kemudian penelitian dan pengembangan ini dikenalkan dalam pertemuan MGMP Ekonomi SMA di Kabupaten Lumajang, yang mendapatkan respons dan sambutan positif.

\section{KESIMPULAN DAN SARAN}

Berdasarkan hasil analisis dan pembahasan, dapat disimpulkan bahwa :

1. Proses pengembangan produk dalam penelitian ini menggunakan model Plomp (2013) Ketiga uji kualitas produk pengembangan (kevalidan, kepraktisan, dan keefektifan) mendapatkan nilai baik. Uji Ahli menyatakan bahwa Model Budget Run dan TI didasarkan pada landasan teori yang kuat, dengan komponen yang saling berkaitan secara konsisten. Guru/pengguna menyatakan bahwa prosedur atau tahapan dalam model jelas dan dapat dilaksanakan.

2. Efektivitas penerapan Model Budget Run dan TI menunjukkan: (1) respons dan minat peserta didik positif, 91\% peserta didik menyatakan bahwa Model Budget Run dan TI menyenangkan dan tidak membosankan, $85 \%$ peserta didik menyatakan bahwa Budget Run dan TI memudahkan mereka dalam memahami jenis belanja dan pendapatan negara serta mengajarkan tentang kerjasama, pengambilan keputusan, menyimpulkan dan mengemukakan pendapat. Sedangkan 98\% peserta didik setuju bahwa model ini mengajarkan nilai-nilai peduli dan integritas terhadap APBN-APBD. (2) Model Budget Run dan TI meningkatkan hasil belajar Peserta Didik, hal ini ditandai dengan tercapainya ketuntasan klasikal setelah model diterapkan. 79\% Peserta didik dinyatakan tuntas belajar. Jumlah ini lebih banyak dibandingkan hasil sebelum tindakan dilakukan, dimana hanya ada 22\% Peserta Didik yang tuntas belajar.

Berdasarkan paparan Model Budget Run dan TI, serta hasil uji coba, maka saran yang dapat dipertimbangkan: (1) Agar tujuan utama pembelajaran tercapai, tahap mengkomunikasikan dan refleksi belajar mutlak dilaksanakan. Hal ini diperlukan agar pembelajaran berbasis permainan tidak dijadikan sebagai alat hiburan semata (2) Perbaikan terhadap produk pengembangan ini dapat terus dilakukan serta disesuaikan sehingga menghasilkan model pembelajaran yang ideal, dan dapat disosialisasikan, agar dapat dipakai sebagai salah satu alternatif model pembelajaran ekonomi di kelas.

\section{DAFTAR RUJUKAN}

Akker, J. van den. (1999). Principles and Methods of Development Research. dalam Plomp, T; Nieveen, N; Gustafson, K; Branch, R.M; dan van den Akker, J (eds). Design Approaches and Tools in Education and Training. London: Kluwer Academic Publisher.

Ariyanti., Wahyono, H., \& Hariyanto A. (2016). Model Pembelajaran Ekonomi MicMac : Rancangan dan Pengembangan. Prosiding Seminar Nasional dan Call for Paper NCEE

Becker, W. E. (2004). Good-Bye Old, Hello New In Teaching Economics. Australasian Journal of Economics Education Vol. 1 No. 1, March 2004 (Page5-16).

Bosch, T. (2009). Using Online Social Networking For Teaching And Learning: Facebook Use At The University Of Cape Town. Communication, 35(2): 185-200.

Cruickshank, D.R., Jenkins, D.B., \& Metcalf, K. K. (2014). Perilaku Mengajar. Edisi 6-Buku 2. Jakarta. Mc Graw Hill dan Salemba Empat. 
Eggen, P. \& Kauchak, D. (2012). Strategi dan Model Pembelajaran: Mengajarkan Konten dan Keterampilan Berpikir. Edisi 6. Boston: Pearson Education.

Ellis, S. \& Varua. (2011). Responding To Student Perceptions Of Education Quuality In Economics And Accounting Courses. Australasian Journal of Economics Education, Volume 8, Number 2, 2011, pp.43-62.

Hasnawati. (2006). Pendekatan Contextual Teaching Learning Hubungannya Dengan Evaluasi Pembelajaran. Jurnal Ekonomi dan Pendidikan, Vol.3 No. 1 April 2006.

Lim, A. (2016). Reflections On The Transition From Economics Student To Economics Tutor, Australasian Journal of Economics Education, Volume 13, Number 2, 2016, pp.32-51.

Mali SM \& Hassan SSS. (2013). Students' Acceptance Using Facebook As A Learning Tool: A Case Study. International Journal of Asian Social Science.3(9):2019-2025

Mardiana, H. (2016). Social Media And Implication For Education: Casestudy In Faculty Of Technology And Science Universitas Buddhi Dharma, Tangerang, Indonesia. Printed Journal: Sains Terapan dan Teknologi FST Buddhi Dharma ISSN: 2541-1268 Vol. 1 No. 1, Desember 2016

Neef, N.A., Perrin, C.J., Haberlin, A.T. \& Rodrigues, L.C. (2011). Studying As Fun And Games: Effects On College Students' Quiz Performance. Journal Of Applied Behavior Analysis. Number 4 (Winter 2011) Page 897-901

Nuraini, U. (2014). Pengembangan Skenario Pembelajaran Project Based Learning Pada Mata Pelajaran Ekonomi SMA. Tesis (Tidak diterbitkan). PPS-Universitas Negeri Malang

Nurhadi. (2002). Pembelajaran Kontekstual. Malang. Universitas Negeri Malang

Plomp, T. (2013). Educational Design Research : An Introduction Akker, Bannan, Kelly, Nieeven, Plomp On Educational Design Research Part A : An Introduction. Tjeerd Plomp \& Nienke Nieeven (Editors). SLO. Netherlands Institute for Curriculum Development. PP (10-51)

Putri RD \& Wahyono H \& Pranowo B. (2014). Pengembangan Model Pembelajaran Ekonomi SMA The Money Adventure (TMA): Prosiding Seminar Nasional dan Call For Paper Pluralisme Dalam Ekonomi dan Pendidikan, Vol 1 tahun 2014.

Rodkroh P, Suwannatthachote P, \& Kaemkate W. (2013). Problem-Based Educational Game Becomes Student-Centered Learning Environment. IADIS International Conference on Cognition and Exploratory Learning in Digital Age (CELDA 2013)

Sato, A. \& de Haan, J. (2016). Applying an Experiential Learning Model to the Teaching of Gateway Strategy Board Games. International Journal of Instruction, January 2016 Vol.9, No.1.

Stokes, A. \& Wright, S. (2012). More Effectively Engaging Students In University Economics Courses, Australasian Journal of Economics Education, Volume 9, Number 1, 2012, pp.120.

www.kemenkeu.go.id. diakses pada tanggal 1 Maret 201821.15

www.kpk.go.id. diakses pada tanggal 3 Maret 201802.30

Yeunglamko, Louis K.C. (2011). From Discontent To Reform: Towards A Multidisciplinary Approach To The Study Of Economics. Australasian Journal of Economics Education Volume 8, Number 1, 2011, pp.69-86 